\title{
Serum Procalcitonin as Outcome Predictors in Deep Neck Infections
}

\author{
Panote Kameshwar*, Worawat Rawangban and Napadon Tangjaturonrasme \\ Department of Otolaryngology, Faculty of Medicine, Thailand \\ *Corresponding author: Panote Kameshwar, Department of Otolaryngology, Faculty of Medicine, Thailand
}

\begin{tabular}{|c|c|}
\hline ARTICLE INFO & ABSTRACT \\
\hline & Objectives: The Deep Neck Space infections are at the anatomically complex \\
\hline Published: 羺 October 24, 2019 & $\begin{array}{l}\text { spaces of the neck. Despite advancing antibiotics, there is potential morbidity and } \\
\text { complications. Assessing infections has relied on clinical examination and traditional }\end{array}$ \\
\hline $\begin{array}{l}\text { Citation: Panote Kameshwar, Worawat } \\
\text { Rawangban, Napadon Tangjaturonr- } \\
\text { asme. Serum Procalcitonin as Outcome }\end{array}$ & $\begin{array}{l}\text { WBCs. Procalcitonin has emerged as a more specific marker for the severity of bacterial } \\
\text { infections. We assess the potential role of Procalcitonin to the outcome of Deep neck } \\
\text { infections. }\end{array}$ \\
\hline $\begin{array}{l}\text { Predictors in Deep Neck Infections. Bi- } \\
\text { omed J Sci \& Tech Res 22(2)-2019. BJSTR. } \\
\text { MS.ID.003729. }\end{array}$ & $\begin{array}{l}\text { Methods: A prospective study was carried out between August } 2017 \text { and December } \\
\text { 2018. Patient with deep neck infections diagnosed by history and physical examination } \\
\text { were recruited. Baseline data, along with the serum procalcitonin were obtained. }\end{array}$ \\
\hline $\begin{array}{l}\text { Keywords: Deep Neck Infections; Procal- } \\
\text { citonin; Complication; Reexploration }\end{array}$ & $\begin{array}{l}\text { Treatment was decided by case. Serum procalcitonin was measured before admission } \\
\text { and } 24-48 \text { hours after proper treatment. Clinical outcome was recorded and analyzed for } \\
\text { the correlation with serum procalcitonin. }\end{array}$ \\
\hline \multirow[t]{2}{*}{$\begin{array}{l}\text { Abbreviations: CRP: C-Reactive Protein; } \\
\text { ESR: Erythrocyte Sedimentation Rate; } \\
\text { WBC: White Blood Cells; TNF: Tumor Ne- } \\
\text { crosis Factor }\end{array}$} & $\begin{array}{l}\text { Result: } 33 \text { patients enrolled in } 17 \text { months. The mean pre-treatment Procalcitonin } \\
\text { level was } 2.34+/-4.64 \text { microgram/liters (range } 0.04-21.15) \text {. A relation was found } \\
\text { with the length of stay ( } \mathrm{p}=0.043) \text {, and the body temperature }(\mathrm{p}<0.001) \text {. The second } \\
\text { procalcitonin level, was found to increase in } 11(36.7 \%) \text { patients and was associated } \\
\text { with the status of re- exploration }(\mathrm{p}=0.008) \text {. }\end{array}$ \\
\hline & $\begin{array}{l}\text { Conclusion: Procalcitonin proved beneficial in deep neck infections. Rising of } \\
\text { Procalcitonin level in } 24-48 \text { hours after initial drainge has a high sensitivity, and a high } \\
\text { negative predictive value for predicting complications, and reexploration. Higher serum } \\
\text { Procalcitonin is also associated to deep neck Infections by days of hospitalisation, and } \\
\text { body tempurature. }\end{array}$ \\
\hline
\end{tabular}

\section{Short Communication}

The deep neck space infections are infections of the anatomically complex spaces of the neck. The infections usually extend through the planes and may result in poor localization. Clinical evaluation is challenging, and difficult in localizing the exact spaces. Physical evaluation alone has shown to underestimate the extent of deep neck infection up to $70 \%$ of patients [1]. Precise drainage to the location of the abscess is crucial but is limited by the complex anatomical structure. Resistant organisms are increasing and results in antibiotics failure. Thus, persistent abscess or reaccumulation of an an abscess after surgical drainage is common. One study had up to $38 \%$ (64 of 170) patients with persistent drainage for more than thirty days [2]. Worsening in infection warrants possible re-evaluation or possible re- exploration. Leukocytosis in the complete blood count is commonly seen. It is used in both in diagnosing, and in following-up. Monitoring for changes in clinical status, in conjunction to the white cell count, and is the standard for evaluating patients [3]. Apart for WBC, other inflammatory markers, such as C-Reactive protein (CRP), Erythrocyte sedimentation rate (ESR), have been applied in the evaluation of infection and inflammations.

Reports in deep neck infections has related a high CRP to a prolonged hospital stay [4], persistent discharge [2], and abscess size [5]. The main disadvantages of many current inflammatory markers, such as C-reactive protein (CRP) or white blood cells 
(WBC), is the lack of specificity for bacterial infections [6,7]. Procaicitonin is the precursor of the Calcitonin hormone and has emerged in the 1990s as the inflammation marker in vary aspects as it rises in response to an inflammation. Assicot et al. [8] first detected high serum procalcitonin in infections, in early 1993 [8]. Procatcitonin concentration increases in bacterial infections. It is a potentially useful marker for distinguishing between bacterial and viral infections [9-11]. Procalcitonin is produced in response to endotoxin or mediators released in response to bacterial infections, that is, interleukin-18, tumor necrosis factor (TNF)-a, and interleukin- 6 and strongly correlates with extent and severity of bacterial infections [12]. Multiple studies have demonstrated that serum level of Procalcitonin markedly increased in patients with bacterial infection and remain low during viral infections [6].

There is a potential knowledge of procalcitonin to the specific area, in both the pre- and post-treatment period. As to our knowledge, there is no study specific to deep neck infections. Given that evaluating the post-treatment of deep neck infections js critical, and the standard clinical examination and WBC is not specific, Procalcitonin may have benefits as it is specific to bacterial infection, and thus, may predict severity or reflect ongoing infections. The main objectives are to study whether rising of procalcitonin after 24-48 hours of treatment, presumably from ongoing infection, correlates with the complications, the re-exploration, and length of hospital stay of deep neck infections. Other objectives include to study whether the level of procalcitonin correlates with the severity of deep neck infections, which are determined by factors of body temperature, white blood cells, absolute neutrophil count, previous antibiotics, co-morbidities, abscess size, status of multiple space infections, status of microbiological positive, length of hospital stay, size of abscess, and status of surgical case.

\section{Material and Method}

This was a prospective, cohort study, carried out in a tertiarycare, university-based hospital, in Bangkok, between August 2017 and December 2018. This study was approved by the Institutional Review Board of the Faculty of Medicine, Chulalongkorn University (Certificate of Approval CoA 733/59).

Inclusion criteria included the following:

a. Clinical diagnosis of Deep neck infections.

b. Age 18 and above.

c. Admission to the facility.

Exclusion criteria included the following:

a. Any with other site of infection apart the deep neck spaces.

b. Those with causes of known raising or lowering procalcitonin, which are, End-stage-renal-disease (GFR $<15$
$\mathrm{mL} / \mathrm{min} / 1.73 \mathrm{~m}^{2}$ or dialysis), Recent (2 months) of trauma or surgical procedure, Thyroid malignancy, and history of organ failure. Those who wish not to participate were also excluded.

All eligible patients were collected baseline data, including gender, age, personal history of disease, duration of symptoms, and previous medication were obtained. CBC and other basic laboratory ware done at admission, along with the serum procalcitonin at the same time. Imaging was not mandatory and performed in case of uncertain localization, or suspected multiple space infections. Treatment strategy follow standard of care, include empirically intravenous antibiotics and prompt surgical procedure as indicated. The standard indications for surgical drainage are an air-fluid level, a threatened airway from the abscess, or failure to respond to 48- 72 hours of intravenous antibiotics [3]. The patients' blood was routinely examined 24-48 hours after either treatment, either antibiotics alone, or surgical drainage, which serum procalcitonin was also repeated. The length of hospital-stay, and if present, the complications were noted. All patients were closely monitored for the airway obstruction, and definite airway management was performed if necessary. All patients were treated and discharged disregarded to the procalcitonin level, by the same team of surgeons. The blood sampling was standardly done by the same team of nurses and laboratory technicians. A total of 33 patients enrolled in 17 months between August 2017, and December 2018.

Their demographic data, length of stay, length of symptoms, underiying history, laboratory assessments, bacteriologic results, radiologic findings, treatment outcome, and complications were reviewed and analysed. The space involved were described standardly and were organized by their location: face (buccal, canine, masticator, parotid), suprahyoid neck (peritonsillar, submandibular, sublingual, parapharyngeal), infrahyoid neck (anterior visceral), and along the length of the neck (retropharyngeal, danger, prevertebral, carotid). Results were aimed to assess the role of procalcitonin in patients with Deep neck infections. The relation of the Procalcitonin to the patients' history, radiologic data, and bacteriologic data, were calculated. The rising of Procalcitonin was also assessed to predict treatment outcomes. The relation between the Procalcitonin and the results of the treatment, including the length of stay, the rate of complication, and the rate of re-exploration, were analysed as the primary outcome. The secondary outcomes were its relation to the severity including, the length of symptoms prior to arrival, body temperature, neutrophil count, previous antibiotics status, co-morbidities, abscess diameter, multiple space infections, positive culture, and status of surgical condition. Rising of the procalcitonin was also assessed in relation to the treatment results, including the length of stay, the rate of complication, and the rate of re-exploration. A Receiver Operating Characteristic (ROC) curve analysis was calculated for a cut-point to predict the treatment outcomes. 


\section{Results}

A total of 33 patients enrolled in 17 months between August 2017 and December 2018. A normality was determined by the Shapiro-Wilk test, A non- normal distribution was calculated, and thus, non-parametric statistics were applied. The baseline characteristics is shown in Table 1 . The categorical variables are listed in frequency and percentages. The continuous variables were listed in mean + SD or median (Inter-quartile range; IQR). Prior to admission, 11 of the 33 patients had taken previous oral antibiotics. Diabetes mellitus (8 cases), and HIV infection (2 cases) were the common associated medical comorbidities. Laboratory investigation revealed leukocytosis. The mean white cell count was 15,680 per mcL of blood. The mean initial procalcitonin level was $2.34 \mathrm{e} / \mathrm{L}$. Infection was mostly diagnosed in the peritonsillar space in 6 cases, the submandibular space in 5 cases, and the parapharyngeal space in 4 cases. Table 2 listed the space involvement of the 33 patients. Infection was found to involve in two or more space in 6 cases. Twenty-five cases (75.8\%) was treated surgically. Of the 25 cases treated surgically, 3 did not obtained pus, and 10 did not produce any organism on aerobic culture, The organism from the remaining 12 cases consisted of Klebsiella pneumoniae in 2 cases, Escherichia coli in 2 cases, and Enterococcus faecium, Staphylococcus epidermidis, Group C Streptococcus, Group G Streptococcus, Streptococcus constellatus, Porphyromonas sp. and Salmonella sp., in one case each.

Table 1: Baseline characteristics of patients.

\begin{tabular}{|c|c|}
\hline Characteristics & All Patients $(n=33)$ \\
\hline Age-yr & $44.94 \pm 16.82$ \\
\hline Male sex - $(\%)$ & $19(57.6)$ \\
\hline \multicolumn{2}{|c|}{ Preexisting Condition } \\
\hline $\mathrm{DM}-(\%)$ & $8(24.2)$ \\
\hline Immunocompromise Host — (\%) & $3(9.1)$ \\
\hline Immunodeficiency & $2(6.1)$ \\
\hline Still's disease & $1(3.0)$ \\
\hline Duration of the onset (days) & $6.82+/-5.78$ \\
\hline Previous AT8 - (\%) & $11(33.3)$ \\
\hline \multicolumn{2}{|c|}{ Physiological Variables } \\
\hline Fever $(\mathrm{BT} \geq 37.8)-(\%)$ & $17(51.5)$ \\
\hline Body temperature - Celsius & $37.77+/-0.93$ \\
\hline WBC count - per mcL of blood & $15,687.27+/-8,276.64$ \\
\hline $\begin{array}{l}\text { Absolute neutrophil count - per } \mu \mathrm{L} \\
\text { of blood }\end{array}$ & $12,528.24+/-8,195.81$ \\
\hline \multicolumn{2}{|c|}{ Procalcitonin Level } \\
\hline $\begin{array}{c}\text { Pre-treatment Procalcitonin level } \\
\qquad-\mu \mathrm{g} / \mathrm{L}\end{array}$ & $2.34+/-4.64$ (range 0.04-21.15) \\
\hline $\begin{array}{l}\text { Post-treatment Procalcitonin level } \\
\qquad \mu \mathrm{g} / \mathrm{L}\end{array}$ & $2.87+/-6.45$ (range $0.03-27.70$ ) \\
\hline CT done $-(\%)$ & $19(57.6)$ \\
\hline Abscess found in CT scan - (\%) & $16(84.2)$ \\
\hline Average abscess diameter - cm & $3.63+/-1.86$ \\
\hline \multicolumn{2}{|c|}{ Space Involvement } \\
\hline
\end{tabular}

\begin{tabular}{|c|c|}
\hline Multiple space involvement - (\%) & $6(18.2)$ \\
\hline Single space involvement $-(\%)$ & $27(81.1)$ \\
\hline \multicolumn{2}{|c|}{ Treatment Results } \\
\hline Surgical case $-(\%)$ & $25(75.8)$ \\
\hline non-surgical case $-(\%)$ & $8(24.2)$ \\
\hline Complications - $(\%)$ & $5(15.2)$ \\
\hline Re-exploration case & 4 \\
\hline Mediatinitis & 1 \\
\hline Length of stay - days & $11.02+/-10.51$ (Range 2-49) \\
\hline
\end{tabular}

Table 2: Distribution of the spaces involved.

\begin{tabular}{|c|c|c|}
\hline Space & $\begin{array}{c}\mathbf{N}=\mathbf{3 3} \\
\mathbf{( 1 0 0 \% )}\end{array}$ & Remark \\
\hline Peritonsillar & $6(18.1 \%)$ & $2 / 6$ had procalcitonin rising \\
\hline Multiple spaces & $6(18.1 \%)$ & $\begin{array}{c}4 / 6 \text { had procalcitonin rising. Of those } \\
\text { 4, 2 had been re-explored. }\end{array}$ \\
\hline Submandibular & $5(15.2 \%)$ & $\begin{array}{c}1 / 5 \text { had procalcitonin rising, which } \\
\text { also had been re-explored. }\end{array}$ \\
\hline Parapharyngeal & $4(12.1 \%)$ & $2 / 4$ had procalcitonin rising. \\
\hline Prevertebral & $3(9.1 \%)$ & $\begin{array}{c}1 / 3 \text { had procalcitonin rising, which } \\
\text { also complicated to mediastinitis. }\end{array}$ \\
\hline Retropharyngeal & $2(6.1 \%)$ & $\begin{array}{c}1 / 2 \text { had procalcitonin rising, which } \\
\text { also had been re-explored. }\end{array}$ \\
\hline Masticator & $2(6.1 \%)$ & \\
\hline Parotid & $2(6.1 \%)$ & \\
\hline Submental & $1(3.0 \%)$ & \\
\hline Buccal & $1(3.0 \%)$ & \\
\hline Anterior visceral & $1(3.0 \%)$ & \\
\hline
\end{tabular}

The second procalcitonin level, was sampled after the treatment 24-48 hours. Comparing to the patient's own initial level, the posttreatment Procalcitonin was found to increase in 11 (33.7\%) of the patients, while 22 (66.6\%) did not. A Fisher's Exact test was calculated for the correlation between the status of procalcitonin rising, and the complications. The complications were found in $5(15.1 \%)$ cases, with 4 as persistent infection requiring reexploration for drainage, and 1 as mediastinitis. All of the 5 cases with complications had a rising in post- treatment procalcitonin level, The rising of procalcitonin has a 1.00 sensitivity $(95 \% \mathrm{CI}$ $0.56-1.00$ ) and 0.78 specificity (95\%CI 0.60-0.89) in detecting complication cases. Most of the complications, 4 from 5 cases, were re-exploration. The sensitivity and specificity for those cases, are 1.00 (95\%CI 0.51-1.00) and 0.75 (95\%CI 0.57-0.87), respectively. Among the 22 cases which did not have a rising in procalcitonin, no case had any complication (Table 3). The rising of procalcitonin was also shown to be in association with the status of re-exploration, and complications, with a statistically significance (Table 3). The group with procaicitonin rising also had a longer hospitalization at an average of 14.3 days, compared to 9.36 days of the non-rising group. Spearman's rank correlation determines the relationship between the initial Procaicitonin level and the continuous variables of length of stay, body temperature, WBC count, absolute neutrophil count, and abscess diameter. The results are shown in Table 4, as the procalcitonin is related directly to all of the factors. 
Table 3: Relation of Procalcitonin rising and the complication.

\begin{tabular}{|c|c|c|c|c|}
\hline & $\begin{array}{c}\text { Procalcitonin } \\
\text { Rising }\end{array}$ & $\begin{array}{c}\text { Procalcitonin not } \\
\text { Rising }\end{array}$ & P-Value \\
\hline \multicolumn{5}{|c|}{ Complication } \\
\hline Yes & 5 & 0 & OR=NA & $0.002^{*}$ \\
\hline No & 6 & 22 & & \\
\hline \multicolumn{5}{|c|}{ Re-exploration } \\
\hline Yes & 4 & 0 & OR=NA & $0.008^{*}$ \\
\hline No & 7 & 22 & & \\
\hline
\end{tabular}

Table 4: Relation of Procalcitonin to parameters.

\begin{tabular}{|c|c|c|}
\hline Parameters & $\begin{array}{c}\text { Correlation } \\
\text { Coefficient }\end{array}$ & P Value \\
\hline Length of stay $(\mathrm{N}=33)$ & 0.355 & $0.043^{*}$ \\
\hline Body temperature (N=33) & 0.643 & $<0.001^{*}$ \\
\hline WBC count (N=33) & 0.242 & 0.175 \\
\hline Absolute neutrophil count (N=33) & 0.271 & 0.127 \\
\hline Abscess diameter $(\mathrm{N}=12)$ & 0.273 & 0.391 \\
\hline
\end{tabular}

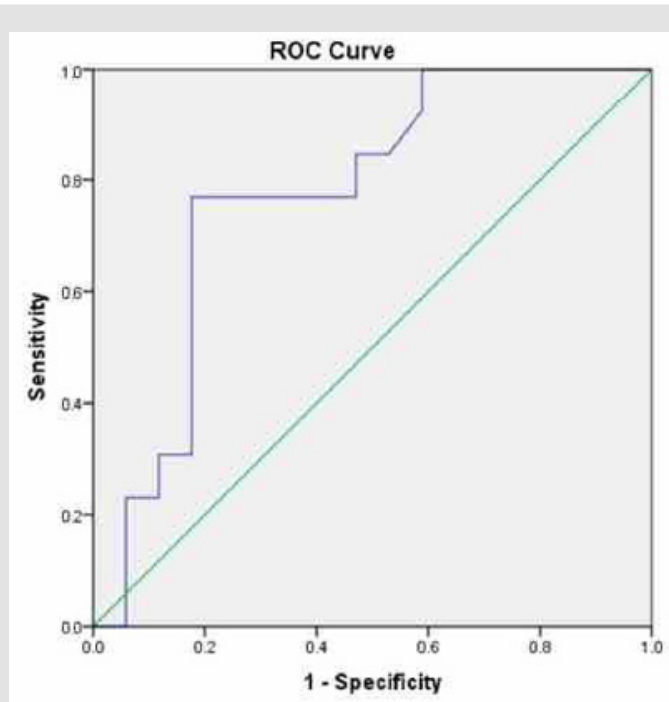

Figure 1: ROC curve of pre-treatment procalcitonin predicting a prolonged LOS of 7 days and over.

Note: Diagonal segments are produced by ties.

A statistical significance is seen with the relation to the length of stay, and the body temperature. A Mann-Whitney U test determines the correlation between the Procalcitonin level and the categorical variables of the status of previous antibiotics use, multiple space, surgical condition, and positive complications. No statistical significance was found (Table 5). A ROC curve analysis was used to find the level of the procalcitonin, predicting a poor outcome of the treatment. Figure 1 shows a ROC curve to predict a prolonged 7 days and over of hospitalized days (Figure 1). Area under the curve of 0.771 indicates a fair predicting test. A procalcitonin level of 0.155 and over, can predict a prolonged stay of 7 days and over, with a $100 \%$ sensitivity (CI $96.30-100 \%$ ), and a $44 \%$ specificity (Cl 34.67-53.77\%). A prolonged stay of 14 days and over, the complication rate, and the re-exploration rate, have an area under the curve of $0.611,0.512$, and 0.451 respectively, which indicate a poor predicting test for those factors.

Table 5: Relation of Procalcitonin to parameters.

\begin{tabular}{|c|c|c|c|}
\hline Characteristics & $\begin{array}{c}\text { Numbers } \\
(\%)\end{array}$ & $\begin{array}{c}\text { Procalcitonin -mean } \\
+/ \text { - sd }\end{array}$ & P-value \\
\hline \multicolumn{4}{|c|}{ Previous Antibiotics } \\
\hline Yes & $11(33.3)$ & $3.57 \mathrm{~V}-7.32$ & \multirow{2}{*}{0.633} \\
\hline No & $22(67.7)$ & $1.73-1-/-2.48$ & \\
\hline \multicolumn{4}{|c|}{ Multiple Space Infection } \\
\hline Yes & $6(18.1)$ & $3.394 /-3.42$ & \multirow{2}{*}{0.183} \\
\hline No & 27 (81.9) & $2.1141-4.89$ & \\
\hline \multicolumn{4}{|c|}{ Complication } \\
\hline Yes & $5(15.2)$ & $0.564 /-0.72$ & \multirow{2}{*}{0.802} \\
\hline No & $28(84.8)$ & $2.66+/-4.98$ & \\
\hline \multicolumn{4}{|c|}{ Surgical case } \\
\hline Yes & $25(75.8)$ & $2.184 /-3.56$ & \multirow{2}{*}{0.475} \\
\hline No & $8(24.2)$ & $2.864 /-7.39$ & \\
\hline
\end{tabular}

\section{Discussion}

In normal subjects circulating procalcitonin concentrations are low $(<0.05 \mathrm{ng} / \mathrm{mL})$ It is detectable within 2-4 hours and peaks within 6- 24 hours, contrast to CRP which begins to rise after 12-24 h and peaks at 48 hours [13]. Unlike WBC, Procalcitonin production is not impaired by neutropenia or other immunosuppressive states, and is valuable in patients with febrile neutropenia [14]. Despite having a below level of detection as a normal value $(<0.01$ microgram/ liters $\}$ in healthy individuals, the cut-points of association shown in each study are high varied, from 0.1 to 1.0 micrograms/liters [6], depending on multiple factors, and presumably organ related, Traditionally, WBC rising has prompted surgeons for possible treatment failures [3]. In recent years, Procalcitonin has been established as an inflammation marker with respect to various infectious disease. If there is infection persistence after treatment, which can be found in cases with difficult surgical drainage, the bacteria and the endotoxins increases. An abnormally high WBC, and high fever usually accompanied, but is also affected by multiple factors. Anti-pyretic and anti-inflammatory medications may have impact. Despite there were no previous study on the relation of procalcitonin and the infections of the deep neck spaces, we believe that procalcitonin, being a proven inflammation marker in various infections of the body, does reflect an infection of the deep neck, especially since it is predominantly bacterial in origin.

Our study did show that procalcitonin reflect a persistent infection in the post-treatment period. None of the 22 cases without procalcitonin rising had complications. In other words, rising of procalcitonin has a 1.00 negative predictive value in predicting complications. High Procalcitonin also correlates to severity, which is had proven true for the first time for infections of the neck spaces 
from our study, by reflecting the length of stay and complication rate. It is comparably similar to studies of other inflammation markers in the deep neck infections. Staffieri et al, demonstrated that leukocyte counts above 11.0 cells x 109/I at presentation had an odd ratio of 3.57 for long (6+ days) of hospital stay [15]. For CRP, studies also have shown that complications and prolonged hospital stay tend to develop deep neck infections, when CRP exceeds 10-15mg/dL [2,4]. The association with re-exploration from our study drew similar conclusions on how procalcitonin exhibit inflammation level in the post-operative period, shown in orthopaedic fracture surgery $[16,17]$, and may necessitate special attention.

\section{Conclusion}

Preliminary report shows Procalcitonin may have a role as an inflammation marker in deep neck infections, as a potential tool in screening complications after initial treatment. Rising of Procalcitonin level in 24-48 hours after initial drainge has a high sensitivity, a high negative predictive value for predicting complications, and reexploration. Higher serum Procalcitonin is also associated to deep neck Infections by days of hospitalisation, Further study and specific designs may be conduct to evaluate specific outcomes.

\section{References}

1. Crespo AN, Chone CT, Fonseca AS, Montenegro MC, Pereira R, et al. (2004) Clinical versus computed tomography evaluation in the diagnosis and management of deep neck infection. Sao Paulo medical journal Revista paulista de medicina 122(6): 259-263.

2. Liu SA, Liang MT, Wang CP, Wang CC, Lin WD, et al. (2009) Preoperative blood sugar and C- reactive protein associated with persistent discharge after incision and drainage for patients with deep neck abscesses. Clinical otolaryngology 34(4): 336-342.

3. Flint PW, Thomas JR Cummings Otolaryngology: Head and Neck Surgery. Elsevier/Saunders.

4. Wang LF, Tai CF, Kuo WR, Chien CY (2010) Predisposing factors of complicated deep neck infections: 12-year experience at a single institution. Journal of otolaryngology 39(4): 335-341.

5. Garca MF, Budak A, Demir N, Cankaya H, Kiroglu AF (2014) Characteristics of deep neck infection in children according to weight percentile. Clinical and experimental otorhinolaryngology 7(2): 133-137.

ISSN: 2574-1241

DOI: 10.26717/BJSTR.2019.22.003729

Panote Kameshwar. Biomed J Sci \& Tech Res

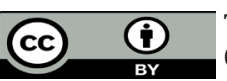

This work is licensed under Creative Commons Attribution 4.0 License

Submission Link: https://biomedres.us/submit-manuscript.php
6. Schuetz P, Albrich W, Mueller B (2011) Procalcitonin for diagnosis of infection and guide to antibiotic decisions: past, present and future. BMC medicine 9: 107.

7. Linscheid P, Seboek D, Nylen ES, Langer I, Schlatter M, et al. (2003) In vitro and in vivo calcitonin | gene expression in parenchymal cells: a novel product of human adipose tissue. Endocrinology 144(12): 55785584.

8. Assicot M, Gendrel D, Carsin H, Raymond J, Guilbaud J, et al. (1993) High serum procalcitonin concentrations in patients with sepsis and infection. Lancet 341(8844): 515-518.

9. Gendrel D, Raymond J, Coste J, Moulin F, Lorrot M, et al. (1999) Comparison of procalcitonin with C-reactive protein, interleukin 6 and interferon-alpha for differentiation of bacterial vs. viral infections. The Pediatric infectious disease journal 18(10): 875-881.

10. Muller B, Harbarth S, Stolz D, Bingisser R, Mueller C, et al. (2007) Diagnostic and prognostic accuracy of clinical and laboratory parameters in community-acquired pneumonia. BMC infectious diseases 7: 10.

11. Christ Crain M, Muller B (2007) Biomarkers in respiratory tract infections: diagnostic guides to antibiotic prescription, prognostic markers and mediators. The European respiratory journal 30(3): 556573.

12. Gogos CA, Drosou E, Bassaris HP, Skoutelis A (2000) Pro- versus antiinflammatory cytokine profile in patients with severe sepsis: a marker for prognosis and future therapeutic options, The Journal of infectious diseases 181(1): 176-180.

13. Kibe S, Adams K, Barlow G (2011) Diagnostic and prognostic biomarkers of sepsis in critical care. The Journal of antimicrobial chemotherapy 66(2): ii33-40.

14. Sakr Y, Sponholz C, Tuche F, Brunkhorst F, Reinhart K (2008) The role of procalcitonin in febrile neutropenic patients: review of the literature. Infection 36(5): 396-407.

15. Staffieri C, Fasanaro E, Favaretto N, La Torre FB, Sanguin S, et al. (2014) Multivariate approach to investigating prognostic factors in deep neck infections. European archives of oto-rhino-laryngology 271(7): 20612067.

16. Yasmin D, Bulut G, Yildiz M (2006) [Can procalcitonin be used for the diagnosis and follow-up of postoperative complications after fracture surgery?]. Acta orthopaedica et traumatologica turcica 40(1): 15-21.

17. Bulut G, Yasmin D, Ak D, Yyldyz M (2010) Value of procalcitonin in differentiating post-surgical systemic and infectious complications from inflammatory reaction caused by surgical trauma in fracture surgery: preliminary report. European Journal of Orthopaedic Surgery Traumatology 20(1): 1-10.

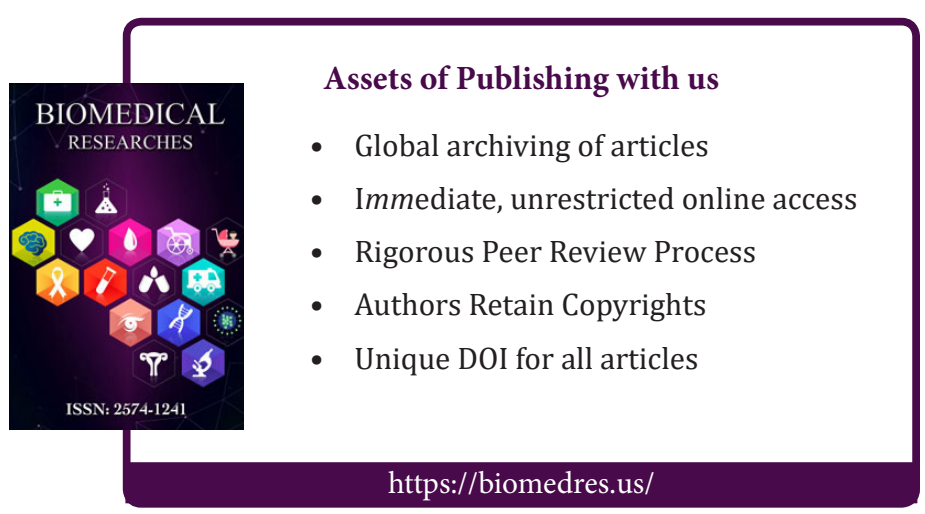

